\title{
Cytotoxicity and genotoxicity of natural resin-based experimental endodontic sealers
}

\author{
Gleyce O. Silva ${ }^{1} \cdot$ Bruno N. Cavalcanti $^{1,3} \cdot$ Tatiana R. Oliveira $^{1} \cdot$ Claudia V. Bin $^{1}$. \\ Samira E. A. Camargo ${ }^{2}$ - Carlos H. R. Camargo ${ }^{1}$
}

Received: 25 October 2013 / Accepted: 13 August 2015 / Published online: 29 August 2015

(C) Springer-Verlag Berlin Heidelberg 2015

\begin{abstract}
Objectives The development of endodontic sealers based on natural resins seems to be promising, given their improved biological properties. This study evaluated the cytotoxic and genotoxic effects of two experimental root canal sealers, based on extracts from Copaifera multijuga and Ricinus communis (castor oil polymer), comparing them to synthetic resin-based sealers: a single methacrylate-based, a multi-methacrylatebased, and an epoxy resin-based sealers.

Materials and methods Sealers were prepared, set, and exposed to cell culture medium for $24 \mathrm{~h}$ at $37{ }^{\circ} \mathrm{C}$ with $\mathrm{CO}_{2}$. V79 cells were exposed to serial dilutions of the extracts of each sealer for $24 \mathrm{~h}$. Cell viability was measured by the MTT assay and genotoxicity was assessed by the formation of micronuclei.

Results The single methacrylate-based sealer had the most cytotoxic effects, with significant reduction in cell viability in all dilutions of the extract. The castor oil polymer-based sealer was, on the other hand, the most biocompatible sealer, with no cytotoxic effects at any concentration. All tested sealers were not genotoxic, excepting the single methacrylate-based sealer.
\end{abstract}

Carlos H. R. Camargo

henrique@fosjc.unesp.br

1 Department of Restorative Dentistry, Institute of Science and Technology, Univ. Estadual Paulista, Av. Eng. Francisco Jose Longo, 777, São José dos Campos, SP 12245-000, Brazil

2 Department of Biosciences, Institute of Science and Technology, Univ. Estadual Paulista (UNESP), São José dos Campos, Brazil

3 Department of Cariology, Restorative Sciences and Endodontics, School of Dentistry, University of Michigan, Ann Arbor, MI, USA
Conclusions The tested natural resin-based sealers presented low cytotoxic and no genotoxic effects on cell cultures.

Clinical relevance These results may suggest a good alternative to develop new endodontic sealers, in order to achieve better biological response and healing, when compared to commercially available sealers.

Keywords Biocompatibility $\cdot$ Root canal sealer . Cytotoxicity $\cdot$ Genotoxicity

\section{Introduction}

Despite advances in the development of new endodontic sealers, it is clear that these materials still have significant limitations, mainly in the biological aspect [1]. Different materials have been used as bases for root canal sealers, and, recently, it is well accepted that natural products, especially those derived from plant extracts or from fermentation of bacteria, can have medicinal value or provide better biocompatibility. This can be of interest in endodontics, since a permanent irritation can maintain a chronic inflammatory response for undetermined time $[2,3]$.

In this context, an experimental root canal sealer based on the Copaifera multijuga oil-resin was developed, by associating this resin to calcium hydroxide and zinc oxide [4]. This oil-resin has a number of positive properties, namely the antiinflammatory, antiseptic, antibacterial, and antifungal activities [5-8]. Another sealer, based on castor oil polymer, is obtained from Ricinus communis [9], having more than $80 \%$ of its composition from ricinoleic acid triglyceride. Studies report that this experimental sealer is biocompatible, promotes healing, and presents antibacterial activity, good mechanical properties, and low cost $[9,10]$. However, although these good properties from experimental sealers have 
been shortly described in the literature, no other study has assessed their level of cytotoxicity or genotoxicity when compared to other sealers available in the market.

Given this gap in the knowledge, the purpose of this study was to evaluate in vitro the cytotoxic and genotoxic effects of these two experimental root canal sealers. It was hypothesized that both natural sealers would be biocompatible, presenting lower cytotoxic and genotoxic levels than synthetic resin sealers.

\section{Materials and methods}

\section{Preparation of extracts}

Five sealers were used in this study: an epoxy resin-based sealer-Epoxy (AHPlus, Dentsply De Trey, Germany), a single methacrylate-based sealer-single methacrylate (EndoREZ, Ultradent, USA), a multi-methacrylate-based sealer-multi-methacrylate (RealSeal SE, SybronEndo, USA), an experimental sealer based on C. multijuga oil-resin - copaifera, and an experimental root canal sealer based on the polymer from R. communis - castor oil (Polifil, Poliquil, Brazil). Their complete compositions are described in Table 1.

All commercially available sealers (synthetic resin-based sealers) were prepared according to the manufacturer's instructions. Natural resin-based sealers were prepared by mixing components as follows: $0.43 \mathrm{~g}$ of copaifera resin powder to $0.2 \mathrm{~mL}$ of liquid, and $0.44 \mathrm{~g}$ of castor oil paste with $0.18 \mathrm{~g}$ of liquid. Portions of each sealer were mixed and placed in a 24-well plate at a thickness of $2 \mathrm{~mm}$ and then incubated at $37^{\circ} \mathrm{C}$ for $12 \mathrm{~h}$ immediately after mixing. Single methacrylate
(EndoRez) specimens were covered with laboratory film and light polymerized for $40 \mathrm{~s}\left(780 \mathrm{~mW} / \mathrm{cm}^{2}\right)$.

Each test specimen was then covered with $2.5 \mathrm{~mL}$ of cell culture medium (Dulbecco's modified Eagle medium (DMEM), Cultilab, Brazil), supplemented by $10 \%$ fetal bovine serum (FBS) and $1 \%$ from a stock solution of penicillin/ streptomycin $(10,000 \mathrm{U} / \mathrm{mL})$, and incubated for $24 \mathrm{~h}$ at $37^{\circ} \mathrm{C}$. The original extracts $(1: 1)$ were prepared following the recommendations of the ISO 10993 at a rate of $82.4 \mathrm{~mm}^{2}$ sample surface area $/ \mathrm{mL}$ cell culture medium.

\section{Cytotoxicity test}

Chinese hamster fibroblasts (V79) were cultured in DMEM supplemented by $10 \% \mathrm{FBS}$, penicillin, and streptomycin at $37^{\circ} \mathrm{C}$ and $5 \% \mathrm{CO}_{2}$. Cells $\left(5 \times 10^{3}\right)$ were seeded in each well of a 96-well plate and incubated for $24 \mathrm{~h}$ at $37^{\circ} \mathrm{C}$. Cultures were then exposed to $200 \mu \mathrm{L}$ of the extracts in serial dilutions (1:1, 1:2, 1:4, and 1:8). Cell cultures with supplemented DMEM (FBS and antibiotic/antimycotic solution) were used as controls. After $24 \mathrm{~h}$, cell viability was determined using the MTT assay. Cell cultures were gently washed with phosphatebuffered saline (PBS), and $100 \mu \mathrm{L}$ of MTT solution was added to each well, followed by incubation $\left(1 \mathrm{~h}\right.$ at $\left.37^{\circ} \mathrm{C}\right)$. Reagents were removed and the resulting formazan product was solubilized in $100 \mu \mathrm{L}$ of dimethyl sulfoxide. Optical density was measured in a spectrophotometer at $570 \mathrm{~nm}$. Four replicate cell cultures were exposed to each of the extract serial dilutions in three independent experiments. Absorbance value readings were normalized to untreated control cultures $(100 \%)$, and statistical differences were assessed by ANOVA and Tukey's test $(p<0.05)$.

Table 1 Main components, setting time, and manufacturer of tested sealers

\begin{tabular}{|c|c|c|}
\hline Sealer & Composition & Manufacturer \\
\hline AH Plus & $\begin{array}{l}\text { Paste A: bisphenol-A epoxy resin, bisphenol-F } \\
\text { epoxy resin, calcium tungstate, zirconium oxide, } \\
\text { silica, iron oxide pigments } \\
\text { Paste B: dibenzyldiamine, aminoadamantane, } \\
\text { tricyclodecane-diamine, calcium tungstate, } \\
\text { zirconium oxide, silica, silicone oil }\end{array}$ & $\begin{array}{l}\text { Dentsply De Trey GmbH, } \\
\text { Konstanz, Germany }\end{array}$ \\
\hline EndoREZ & $\begin{array}{l}30 \% \text { UDMA, zinc oxide, barium sulfate, } \\
\text { resins, pigments }\end{array}$ & Ultradent, South Jordan, USA \\
\hline RealSeal SE & $\begin{array}{l}\text { Sealer: BisGMA, ethoxylated BisGMA UDMA, } \\
\text { hydrophilic monomers } \\
\text { Thinning resin: EBPADMA resins with photo } \\
\text { initiator, amines, stabilizer, and red } \# 40\end{array}$ & Sybron Endo, Orange, USA \\
\hline Copaifera & $\begin{array}{l}\text { Powder: zinc oxide, calcium hydroxide, bismuth } \\
\text { subcarbonate, natural resin, borax } \\
\text { Liquid: oil resin from Copaifera multijuga }\end{array}$ & - \\
\hline $\begin{array}{l}\text { Polifill (castor oil polymer sealer) } \\
\text { (Ricinus communis) }\end{array}$ & $\begin{array}{l}\text { Liquid: biphenyl methane isocyanine } \\
\text { Paste: polyester, zinc oxide, distilled water }\end{array}$ & Poliquil, Arararaquara, Brazil \\
\hline
\end{tabular}




\section{Genotoxicity test}

Cells $\left(3 \times 10^{5}\right)$ were seeded on microscopic glass slides and incubated with supplemented DMEM for $24 \mathrm{~h}$ at $37^{\circ} \mathrm{C}$ and $5 \% \mathrm{CO}_{2}$. In this experiment, cells were exposed to the dilution of each sealer that gave cell viability close to $50 \%$, standardizing all samples. Most cytotoxic dilutions were not analyzed because they did not allow cell proliferation, invalidating the analysis. Untreated cell cultures and $5 \mathrm{mM}$ ethyl methanesulfonate (EMS) were used as controls. The formation of micronuclei was analyzed microscopically, using 1000 cells/slide of 2 parallel cultures (slides) per concentration. At least 4 slides derived from 4 independent experiments were analyzed. To validate the micronuclei test, we also analyzed the number of cells in mitosis and in apoptosis. Statistical differences were assessed by ANOVA and Tukey's test $(p<0.05)$.

\section{Results}

\section{Cytotoxicity of root canal sealers}

Cell viability results are shown in Fig. 1. All tested sealers were cytotoxic in more concentrated dilutions, excepting the castor oil polymer-based sealer, which was not cytotoxic in any dilution. The single methacrylate-based sealer was highly
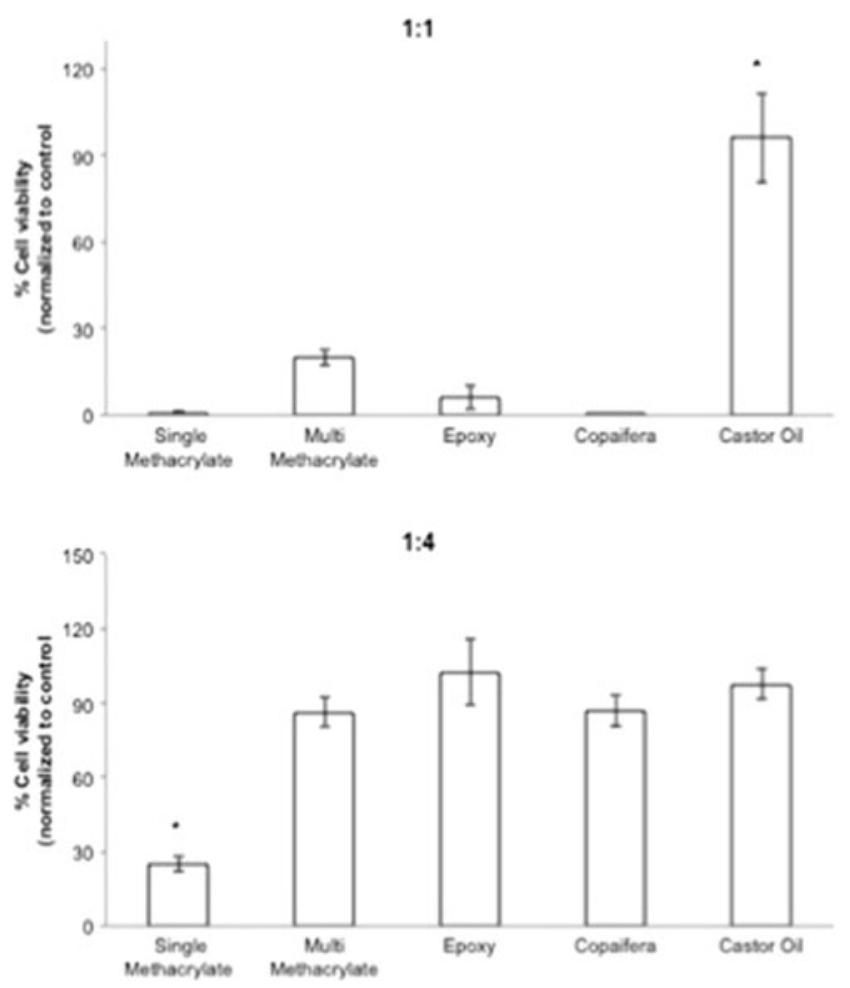

Fig. 1 Cytotoxicity levels ( $\%$ of the untreated control group) for the tested sealers, according to the dilution of the original extract. Four replicates in three independent experiments were analyzed. Bars toxic to the cells, presenting $1.09 \%$ of cell viability in original extract, $23.54 \%$ in 1:4 dilution, and $41.95 \%$ in 1:8 dilution. This means that it was tolerable (viability close to $50 \%$ ), only in the less concentrated dilution. Other tested sealers were in an intermediate level of cytotoxicity, with increased biocompatibility from the 1:2 dilution (for example, the epoxy resin achieved $5.75 \%$ with the original extract and $61.89 \%$ in $1: 2$ dilution) and no cytotoxicity in 1:4 and 1:8 extracts.

\section{Genotoxicity test}

Micronuclei formation in V79 cells exposed to sealer extracts was analyzed, with EMS used as positive control (Fig. 2). The single methacrylate-based sealer was the most genotoxic, with a 14-fold increase of micronuclei number when compared with the untreated cell cultures, even above the number of micronuclei counted in the positive control group (EMS). None of the other sealers had significant genotoxic effect when compared to the untreated cultures. The number of cells in proliferation and cells in apoptosis are shown in Fig. 2, according to the micronuclei formation.

\section{Discussion}

In general, the experimental sealers presented mid to low cytotoxicity and no genotoxicity. The castor oil polymer-based
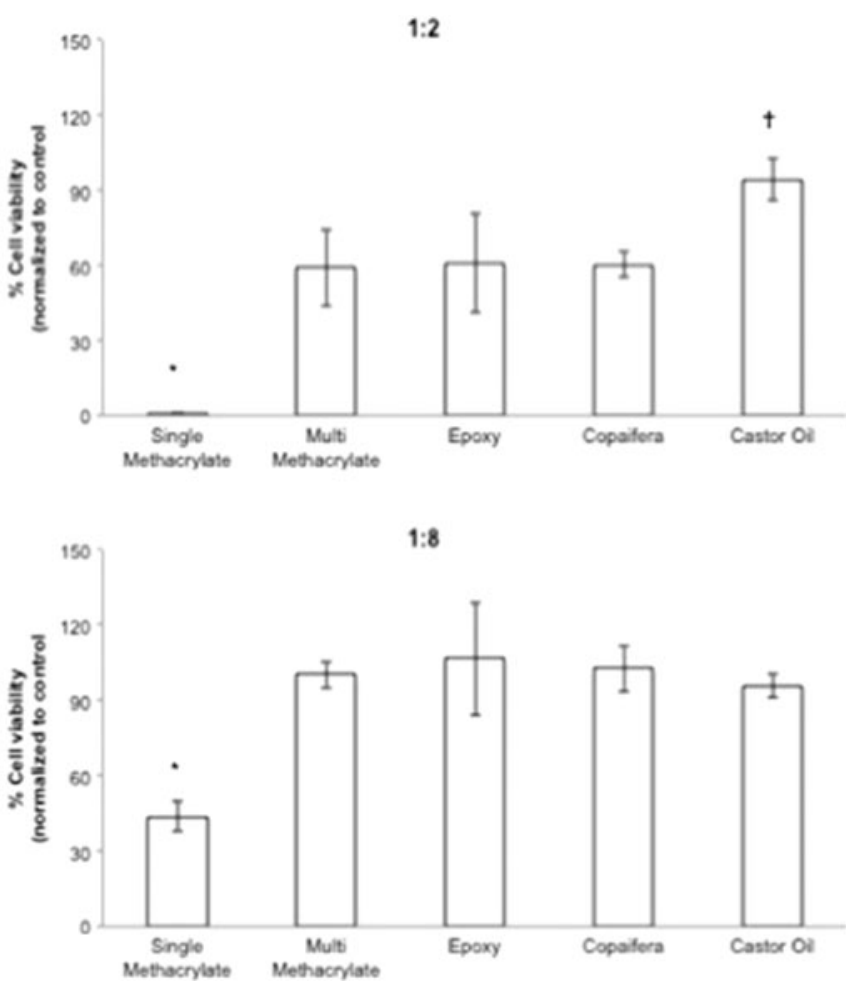

represent mean and standard deviations. Statistical differences $(p<0.05)$ are marked by asterisk and/or cross symbol 
Fig. 2 Genotoxicity levels (micronuclei counting) and cells in mitosis and in apoptosis for the tested sealers. Four replicates in four independent experiments were analyzed. Bars represent mean and standard deviations. Statistical differences $(p<0.05)$ are marked by asterisk, cross symbol, and/or black square

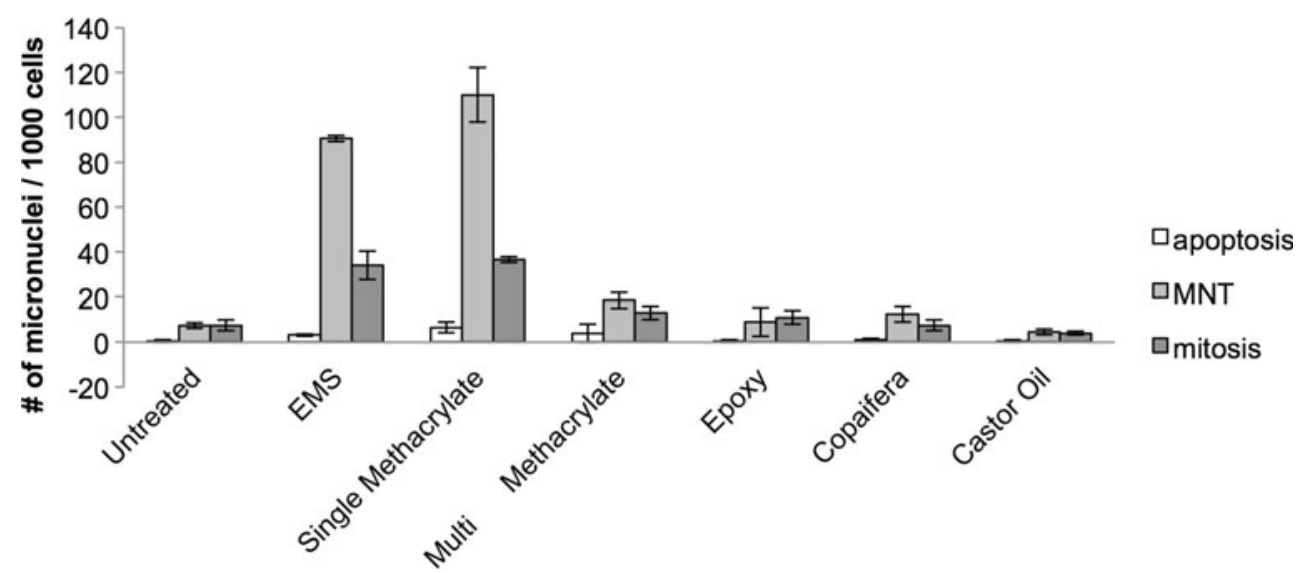

sealer was not cytotoxic and not genotoxic, according to the tests performed in this study, when compared to commercially available synthetic resin-based sealers. The single methacrylate-based sealer presented a high level of cytotoxicity and genotoxicity.

The biological effectiveness of endodontic sealers is important for the success of endodontic therapy. The biological response depends on the molecular interactions that result from the interface between the sealers placed in contact with the tissues [11]. Therefore, a biocompatible sealer should not retard or arrest the process of tissue repair. In this context, the castor oil polymerbased sealer maintained a high level of cell viability consistently at all dilutions, which was recently reported by another study [12]. The C. multijuga-based sealer had cytotoxicity similar to the multi-methacrylate and the epoxy-resin-based sealers, which is among the average for the available sealers. This biocompatibility associated with its physicochemical properties, as required by the American Dental Association (ADA), indicate promise in clinical studies [4], which is even more important if its antimicrobial activity is considered [7]. The literature reports that the cytotoxicity present in this sealer is due to the natural resin (rosin) present in its composition [13].

Regarding the synthetic-resin-based sealers, the initial cytotoxicity of the epoxy-resin sealer was demonstrated previously, also in more concentrated extracts [12, 14-19]. Other studies have reported little or no cytotoxicity of AH Plus; however, they had different experimental conditions [20-22], such as different setting time [12, 19], contact area $[12,14,19]$ and direct or indirect contact of the material with the cells [14]. The same levels of cytotoxicity were observed for the multi-methacrylate-based sealer. The literature reports that self-etching formulations are more biocompatible than regular methacrylate sealers, probably due to the incorporation of a relatively high concentration of polymerizable methacrylate carboxylic acid anhydride in these self-etching sealers [23]. High levels of cytotoxicity were already reported for the regular single methacrylatebased sealer [1, 15, 19, 23-25]. The cytotoxic effect of this material may be caused by the presence of urethane dimethacrylate (UDMA) [26]. In contrast, other studies have shown little or no cytotoxicity of this material [17, $20,21]$, which may also be related to the variability in experimental conditions and biological mechanisms, cell type, method of cell-material contact, preparation of extracts, and exposure time [22].

Genotoxicity testing was performed to complement the biocompatibility screening of the tested sealers. In general, it is expected that a low cytotoxic material should also present low genotoxicity. This was confirmed by our data, where only the single methacrylate-based sealer presented high levels of genotoxicity by remarkable increase in the number of micronuclei. In this case, it is possible that these effects are not only caused by the presence of UDMA. This compound is included in other methacrylate-based sealers, which did not present this pronounced genotoxic effect [12]. It is also possible that the induction of genotoxicity of this sealer is linked to the formation of reactive oxygen species (ROS) and oxidative DNA damage [27]. The castor oil polymer-based sealer did not present any levels of genotoxicity, as well as the copaifera resin-based sealer.

Clearly, the development of experimental sealers, based on natural resin polymers, may be an alternative to achieve better levels of biocompatibility. Of course, methods described here are extensively used in the literature as an initial screening on the biocompatibility of dental materials, not allowing extrapolation to clinical use. However, it may serve as a baseline to develop new sealers, in regard to their ability to promote (or not) hazardous effects to the cells. In this study, the castor oil polymer-based sealer presented impressive results with no levels of cytotoxicity and genotoxicity which, in association with well-developed mechanical properties, could present an almost ideal alternative in this field. 


\section{Conclusion}

Original extracts presented the highest cytotoxicity activity, except for castor oil bean, which was not cytotoxic. The tested sealers did not present expressive cytotoxic levels in more diluted samples, excepting the single methacrylate, which was toxic in all dilutions. For genotoxicity test, single methacrylate was the only presenting genotoxic effects, when compared to the positive control.

Acknowledgments This investigation was supported in part by Research Grant (\#2009/13290-1) from Fundação de Amparo à Pesquisa do Estado de São Paulo (FAPESP)—Brazil.

\section{References}

1. Bouillaguet S, Wataha JC, Lockwood PE, Galgano C, Golay A, Krejci I (2004) Cytotoxicity and sealing properties of four classes of endodontic sealers evaluated by succinic dehydrogenase activity and confocal laser scanning microscopy. Eur J Oral Sci 112:182187

2. Andrighetti-Fröhner CR, Kratz JM, Antonio RV (2006) In vitro testing for genotoxicity of violacein assessed by comet and micronucleus assays. Mutation Res 603:97-103

3. Sabir A, Tabbu CR, Agustiono P, Sosroseno W (2005) Histological analysis of rat dental pulp tissue capped with propolis. J Oral Sci 47: 135-138

4. Garrido AD, Lia RC, Franca SC, da Silva JF, Astolfi-Filho S, Sousa-Neto MD (2010) Laboratory evaluation of the physicochemical properties of a new root canal sealer based on Copaifera multijuga oil-resin. Int Endod J 43:283-291

5. Agra MF, França PF, Barbosa-Filho JM (2007) Synopsis of the plants known as medicinal and poisonous in northeast of Brazil. Rev Bras Farmacogn 17:114-140

6. Lima SR, Junior VF, Christo HB, Pinto AC, Fernandes PD (2003) In vivo and in vitro studies on the anticancer activity of Copaifera multijuga Hayne and its fractions. Phytother Res 17:1048-1053

7. Santos AO, Ueda-Nakamura T, Dias Filho BP, Veiga Junior VF, Pinto AC, Nakamura CV (2008) Antimicrobial activity of Brazilian copaiba oils obtained from different species of the Copaifera genus. Mem Inst Oswaldo Cruz 103:277-281

8. Veiga Jr VF, Rosas EC, Carvalho MV, Henriques MGMO, Pinto AC (2007) Chemical composition and anti-inflammatory activity of copaiba oils from Copaifera cearensis Huber ex Ducke, Copaifera reticulate Ducke and Copaifera multijuga Hayne - a comparative study. J Ethnopharmacol 112:248-254

9. Carvalho TL, Teofilo JM, Araujo CA, Brentegani LG (1997) Chronology of alveolar healing following immediate implantation of Ricinus communis polyurethane resin: histometric analysis in rats. J Biomed Mater Res 37:449-452
10. Barros VM, Rosa AL, Beloti MM, Chierice G (2003) In vivo biocompatibility of three different chemical compositions of Ricinus communis polyurethane. J Biomed Mater Res A 67:235-239

11. Bouillaguet S, Wataha JC, Tay FR, Brackett MG, Lockwood PE (2006) Initial in vitro biological response to contemporary endodontic sealers. J Endod 32:989-992

12. Camargo CH, Camargo SE, Valera MC, Hiller KA, Schmalz G, Schweikl H (2009) The induction of cytotoxicity, oxidative stress, and genotoxicity by root canal sealers in mammalian cells. Oral Surg Oral Med Oral Pathol Oral Radiol Endod 108:952-960

13. Sunzel B, Soderberg TA, Johansson A, Hallmans G, Gref R (1997) The protective effect of zinc on rosin and resin acid toxicity in human polymorphonuclear leukocytes and human gingival fibroblasts in vitro. J Biomed Mater Res 37:20-28

14. Brackett MG, Marshall A, Lockwood PE, Lewis JB, Messer RL, Bouillaguet S, et al. (2008) Cytotoxicity of endodontic materials over 6-weeks ex vivo. Int Endod J 41:1072-1078

15. Al-Hiyasat AS, Tayyar M, Darmani H (2010) Cytotoxicity evaluation of various resin based root canal sealers. Int Endod J 43:148153

16. Correa GT, Veranio GA, Silva LE, Hirata Junior R, Coil JM, Scelza MF (2009) Cytotoxicity evaluation of two root canal sealers and a commercial calcium hydroxide paste on THP1 cell line by trypan blue assay. J Appl Oral Sci 17:457-461

17. Miletic I, Devcic N, Anic I, Borcic J, Karlovic Z, Osmak M (2005) The cytotoxicity of RoekoSeal and AH plus compared during different setting periods. J Endod 31:307-309

18. Huang Y, Fenech M, Shi Q (2011) Micronucleus formation detected by live-cell imaging. Mutagenesis 26:133-138

19. Eldeniz AU, Mustafa K, Orstavik D, Dahl JE (2007) Cytotoxicity of new resin-, calcium hydroxide- and silicone-based root canal sealers on fibroblasts derived from human gingiva and L929 cell lines. Int Endod J 40:329-337

20. Karapinar-Kazandag M, Bayrak OF, Yalvac ME, Ersev H, Tanalp J, Sahin F, et al (2011) Cytotoxicity of 5 endodontic sealers on L929 cell line and human dental pulp cells. Int Endod J 44:626-634

21. Lodiene G, Morisbak E, Bruzell E, Orstavik D (2008) Toxicity evaluation of root canal sealers in vitro. Int Endod J 41:72-77

22. Oztan MD, Yilmaz S, Kalayci A, Zaimoglu L (2003) A comparison of the in vitro cytotoxicity of two root canal sealers. J Oral Rehabil 30:426-429

23. Ames JM, Loushine RJ, Babb BR, Bryan TE, Lockwood PE, Sui $\mathrm{M}$, et al (2009) Contemporary methacrylate resin-based root canal sealers exhibit different degrees of ex vivo cytotoxicity when cured in their self-cured mode. J Endod 35:225-228

24. da Silva PT, Pappen FG, Souza EM, Dias JE, Bonetti Filho I, Carlos IZ, et al (2008) Cytotoxicity evaluation of four endodontic sealers. Braz Dent J 19:228-231

25. Gencoglu N, Sener G, Omurtag GZ, Tozan A, Uslu B, Arbak S, et al (2009) Comparision of biocompatibility and cytotoxicity of two new root canal sealers. Acta Histochem 112:567-575

26. Volk J, Engelmann J, Leyhausen G, Geurtsen W (2006) Effects of three resin monomers on the cellular glutathione concentration of cultured human gingival fibroblasts. Dent Mater 22:499-505

27. Schweikl H, Spagnuolo G, Schmalz G (2006) Genetic and cellular toxicology of dental resin monomers. J Dent Res 85:870-877 